\title{
Gambaran persalinan prematur pada kehamilan remaja di RSUP Prof. Dr. R. D. Kandou Manado periode 1 Januari - 31 Desember 2015
}

\author{
${ }^{1}$ Marnie C. Ondang \\ ${ }^{2}$ Eddy Suparman \\ ${ }^{2}$ Hermie M.M. Tendean
}

\author{
${ }^{1}$ Kandidat skripsi Fakultas Kedokteran Universitas Sam Ratulangi Manado \\ ${ }^{2}$ Bagian Obstetri dan Ginekologi RSUP Prof DR. R. D. Kandou Manado \\ Email: christine_ondang@yahoo.com
}

\begin{abstract}
According to WHO, about 13 millions babies were born prematurely in this world, and less than 1 million premature babies die every year. Around 14 million teenagers become mothers every year and more than $90 \%$ of young mothers were in developing countries. Rate of premature birth around 10-20\% in Indonesia in 2009 which causes Indonesia becomes the big 5 of the most premature births. According to Riskesdas in 2013 pregnancy in the age 10-54 years in Indonesia was 2,68\% higher in cities than in suburban/villages. From women aged 10-54 there are $0.02 \%$ pregnant women under 15 years old. This was a descriptive retrospective, study using medical record data of the patients who had premature labour among teenagers acording to age, education, job, marital status, parity, health, head presentation. The results showed that of 31 cases of premature labours in teenagers, 22 cases or $70.96 \%$ of them are delivered by women age 18 to 19 -year-old, the last education level they had in average is high school which is $64.51 \%$, the majority of them, $93.54 \%$ are working as housewives, $83.87 \%$ are married, 25 cases or $80.64 \%$ of them are primigravida, the highest factors of premature baby, $12.90 \%$ is the ruptured amnion which happened far before the due date of the baby's delivery, and $90.32 \%$ of the case is baby's head in facing-down position. Conclusion: Premature labours were mostly found in the age group of 18 to 19-year-old with ruptured of amnion long before the baby's delivery as the highest complication factor, and utmost cases with the baby's head is in facing-down position.

Keywords: preterm labor, teenagers.
\end{abstract}

\begin{abstract}
Abstrak: Menurut $\mathrm{WHO} \pm 13$ juta bayi lahir prematur di dunia, dan $>1$ juta bayi yang lahir prematur meninggal setiap tahunnya. Sekitar 14 juta anak remaja wanita menjadi ibu setiap tahun dan lebih dari $90 \%$ dari para ibu muda berada di negara berkembang. Angka kelahiran prematur berkisar 10-20\% di Indonesia pada tahun 2009 yang menyebabkan Indonesia masuk dalam peringkat kelima dengan kelahiran prematur terbesar. Berdasarkan Riskesdas 2013 kehamilan umur 10-54 tahun di Indonesia adalah 2,68\%, di perkotaan lebih tinggi dibanding perdesaan. Di antara wanita umur 10-54 tahun terdapat kehamilan umur $<15$ tahun $(0,02 \%)$. Jenis penelitian ialah deskriptif retrospektif, menggunakan data rekam medik pasien yang melahirkan prematur pada usia remaja berdasarkan umur, pendidikan, pekerjaan, status perkawinan, paritas, penyakit/penyulit, presentasi kepala. Dari 31 kasus persalinan prematur pada remaja, didapatkan paling sering pada usia 18-19 tahun sebanyak 22 kasus (70,96\%), pendidikan terakhir terbanyak SMA $(64,51 \%)$, pekerjaan terbanyak IRT $(93,54 \%)$, dengan status menikah $(83,87 \%)$ dan jumlah primigravida 25 kasus $(80,64 \%)$. Penyakit/penyulit persalinan terbanyak Ketuban Pecah Dini $(12,90 \%)$ dengan presentasi letak kepala $(90,32 \%)$. Simpulan: Persalinan prematur pada remaja paling sering ditemukan pada kelompok usia 18-19 tahun dan penyulit tertinggi yaitu ketuban pecah dini dengan jenis presentasi kepala tinggi.
\end{abstract}

Kata kunci: persalinan prematur, kehamilan remaja. 
Persalinan prematur adalah persalinan yang terjadi pada usia kehamilan 22 minggu hingga 37 minggu. Di negara Barat kematian neonatus tinggi yang disebabkan oleh prematuritas sekitar $80 \%$, dan pada bayi yang hidup mengalami permasalahan jangka panjang sekitar $10 \%{ }^{1}$ Di negaranegara berpenghasilan rendah penyebab utama kelahiran prematur meliputi infeksi, malaria, HIV, dan tingkat kehamilan remaja yang tinggi. Sekitar 14 juta anak remaja wanita menjadi ibu setiap tahun. Dan lebih dari $90 \%$ dari para ibu muda berada di negara berkembang. ${ }^{2}$

Menurut WHO, kurang lebih 13 juta bayi lahir prematur di dunia, dan lebih dari 1 juta dari bayi yang lahir prematur meninggal setiap tahunnya. ${ }^{3}$ Kelahiran prematur meningkat dari $7,5 \%$ (2 juta kelahiran $)$ menjadi $8,6 \% \quad(2,2$ juta kelahiran) di dunia. Angka kejadian kelahiran prematur di negara berkembang jauh lebih tinggi, seperti India (30\%), Afrika Selatan (15\%), Sudan (31\%) dan Malaysia (10\%). Angka kelahiran prematur berkisar $10-20 \%$ di Indonesia pada tahun 2009 dan angka ini menyebabkan Indonesia termasuk dalam peringkat kelima dengan kelahiran prematur terbesar. ${ }^{4}$

Berdasarkan Riskesdas

2013

kehamilan umur 10-54 tahun di Indonesia adalah $2,68 \%$, di perkotaan $(2,8 \%)$ lebih tinggi dibanding perdesaan $(2,55 \%)$. Di antara penduduk wanita umur 10-54 tahun terdapat kehamilan pada umur yang sangat muda ( $<15$ tahun), meskipun dengan proporsi yang kecil $(0,02 \%)$. Kesulitan utama dalam persalinan prematur ialah perawatan bayi, yang semakin muda usia kehamilannya semakin besar morbiditas dan mortalitas. Berat badan bayi juga memengaruhi keberhasilan persalinan prematur. ${ }^{1}$ Dapat terjadi pertumbuhan mental-intelektual dan fisik yang kurang menguntungkan sehingga menjadi beban keluarga, masyarakat dan negara. Dalam menanggulangi masalah persalinan prematur, salah satu cara pencegahan melalui faktor risiko terjadinya persalinan prematur. $^{5}$

Faktor ibu, janin dan plasenta sangat mempengaruhi terjadinya persalinan prematur. Beberapa contoh kondisi yang menyebabkan terjadinya persalinan prematur yaitu penyakit ibu selama kehamilan, kehamilan ganda, stress fisik dan mental, kelainan plasenta, nutrisi, medis, infeksi. Secara epidemiologi persalinan prematur berhubungan dengan sosial ekonomi, usia ibu, anomali uterus, riwayat persalinan prematur sebelumnya, riwayat abortus, perokok, dan ras. ${ }^{6}$

Hasil penelitian yang menggunakan data Riset Kesehatan Dasar sejak Januari 2010 sampai Juni 2013, menunjukkan bahwa dari 48.336 wanita yang melahirkan terdapat $36 \%$ ibu yang mengalami kelahiran prematur. ${ }^{2}$ Rumah Sakit Panti Wilasa Citarum pada tahun 2010 didapatkan 90 kasus persalinan prematur. ${ }^{3}$ Kejadian persalinan prematur di RSUP Dr. H. Moch Ansari Saleh Banjarmasin terdapat 63 kasus prematur. ${ }^{7}$ Sedangkan di RSUP Prof. Dr. Kandou Manado pada tahun 2013, terdapat $151 \quad(2,28 \%)$ persalinan prematur dari 6600 jumlah persalinan. ${ }^{6}$

Penelitian ini bertujuan untuk mendapatkan gambaran persalinan prematur pada kehamilan remaja di RSUP Prof. Dr. R.D. Kandou periode 1 Januari sampai 31 Desember 2015.

\section{METODE PENELITIAN}

Jenis penelitian ini ialah deskriptif retrospektif dengan menggunakan data $n$ rekam medik pasien di Instalasi Rekam Medik dan Buku Partus VK RSUP. Prof. Dr. R. D. Kandou Manado. Populasi dari penelitian ini adalah semua pasien usia remaja yang melahirkan di RSUP Prof. Dr. R. D. Kandou, sampel adalah semua pasien remaja yang melahirkan prematur pada periode 1 Januari sampai 31 Desember 2015.

Dari catatan rekam medik meliputi usia kehamilan, umur, pendidikan, pekerjaan, status perkawinan, paritas, penyakit/ penyulit, presentasi kepala. Data yang sudah terkumpul diolah dan disajikan dalam bentuk tabel dan dianalisis berdasarkan hasil persentase. 


\section{HASIL PENELITIAN}

Selama periode 1 Januari-31 Desember 2015 di bagian Obstetri dan Ginekologi Fakultas Kedoteran Unsrat / RSUP Prof. Kandou Manado, tercatat 31 persalinan prematur pada usia remaja. Tabel 1 memperlihatkan 31 kasus $(14,15 \%)$ persalinan prematur pada remaja dari 219 persalinan pada remaja.

Tabel 1. Insiden Jumlah Persalinan Prematur pada Remaja

\begin{tabular}{cccc}
\hline Tahun & $\begin{array}{c}\text { Jumlah } \\
\text { Persalinan } \\
\text { pada } \\
\text { Remaja }\end{array}$ & $\begin{array}{c}\text { Jumlah } \\
\text { Persalinan } \\
\text { Prematur } \\
\text { pada Remaja }\end{array}$ & $\%$ \\
\hline 2015 & 219 & 31 & 14,15 \\
\hline
\end{tabular}

Tabel 2 memperlihatkan usia kehamilan tertinggi pada persalinan remaja yaitu aterm sebanyak 185 kasus $(84,47 \%)$.

Tabel 2. Usia Kehamilan pada Persalinan Remaja

\begin{tabular}{ccc}
\hline Usia & Jumlah & \% \\
Kehamilan & 31 & 14,15 \\
Prematur & 185 & 84,47 \\
Aterm & 3 & 1,36 \\
Postterm & 219 & 100 \\
Total &
\end{tabular}

Tabel 3 memperlihatkan karakteristik pasien berdasarkan umur tertinggi pada 1819 tahun yaitu sebanyak 22 kasus $(70,96 \%)$.

Tabel 3. Karakteristik Ibu berdasarkan Umur

\begin{tabular}{ccc}
\hline $\begin{array}{c}\text { Kelompok } \\
\text { Umur }\end{array}$ & Jumlah & \% \\
\hline $\mathbf{1 2 - 1 3}$ & 2 & 6,45 \\
$\mathbf{1 4 - 1 5}$ & 1 & 3,22 \\
$\mathbf{1 6 - 1 7}$ & 6 & 19,35 \\
$\mathbf{1 8 - 1 9}$ & 22 & 70,96 \\
Total & $\mathbf{3 1}$ & $\mathbf{1 0 0}$ \\
\hline
\end{tabular}

Tabel 4 memperlihatkan karakteristik pasien berdasarkan status pendidikan ibu tertinggi pada SMA/SMK yaitu 20 kasus $(64,51 \%)$.
Tabel 4. Karakteristik Ibu berdasarkan Pendidikan Terakhir

\begin{tabular}{ccc}
\hline $\begin{array}{c}\text { Status } \\
\text { Pendidikan }\end{array}$ & Jumlah & $\boldsymbol{\%}$ \\
\hline SD & 3 & 9,67 \\
SMP & 8 & 25,80 \\
SMA/SMK & 20 & 64,51 \\
Total & $\mathbf{3 1}$ & $\mathbf{1 0 0}$ \\
\hline
\end{tabular}

Tabel 5 memperlihatkan karakteristik pasien berdasarkan pekerjaan tertinggi yaitu IRT/Tidak Bekerja sebanyak 29 kasus $(93,54 \%)$.

Tabel 5. Karakteristik Ibu berdasarkan Pekerjaan

\begin{tabular}{ccc}
\hline $\begin{array}{c}\text { Status } \\
\text { Pekerjaan }\end{array}$ & Jumlah & \% \\
\hline IRT/Tidak & 29 & 93,54 \\
Bekerja & 2 & 6,45 \\
Mahasiswa & $\mathbf{3 1}$ & $\mathbf{1 0 0}$ \\
Total & \\
\hline
\end{tabular}

Tabel 6 memperlihatkan status perkawinan tertinggi yaitu Menikah yaitu 26 kasus $(83,87 \%)$.

Tabel 6. Status Perkawinan Ibu

\begin{tabular}{ccc}
\hline $\begin{array}{c}\text { Status } \\
\text { Perkawinan }\end{array}$ & Jumlah & \% \\
\hline Belum & 5 & 16,12 \\
Menikah & 26 & 83,87 \\
Menikah & $\mathbf{3 1}$ & $\mathbf{1 0 0}$ \\
Total & \\
\hline
\end{tabular}

Tabel 7 memperlihatkan karakteristik pasien berdasarkan paritas tertinggi yaitu primigravida sebanyak 25 kasus $(80,64 \%)$.

Tabel 7. Karakteristik Ibu berdasarkan Status Paritas

\begin{tabular}{ccc}
\hline Paritas & Jumlah & \% \\
\hline Primigravida & 25 & 80,64 \\
Multigravida & 6 & 19,35 \\
Total & $\mathbf{3 1}$ & $\mathbf{1 0 0}$ \\
\hline
\end{tabular}

Tabel 8 memperlihatkan karakteristik pasien berdasarkan penyulit persalinan tertinggi yaitu KPD sebanyak 4 kasus $(12,90 \%)$. 
Tabel 8. Penyakit/Penyulit Persalinan Prematur pada Remaja

\begin{tabular}{ccc}
\hline Penyakit/Penyulit & Jumlah & $\mathbf{\%}$ \\
\hline Preeklampsi/Eklampsi & 2 & 6,45 \\
Ketuban Pecah Dini & 4 & 12,90 \\
Fluor Albus & 1 & 3,22 \\
Anemia & 1 & 3,22 \\
Tidak ada & 23 & 74,19 \\
Total & $\mathbf{3 1}$ & $\mathbf{1 0 0}$ \\
\hline
\end{tabular}

Tabel 9 memperlihatkan jenis presentasi kepala tertinggi yaitu letak kepala sebanyak 28 kasus $(90,32 \%)$.

Tabel 9. Jenis Presentasi Kepala

\begin{tabular}{ccc}
\hline Jenis Presentasi & Jumlah & \% \\
\hline Letak Kepala & 28 & 90,32 \\
Letak Sungsang & 3 & 9,67 \\
Total & $\mathbf{3 1}$ & $\mathbf{1 0 0}$ \\
\hline
\end{tabular}

\section{BAHASAN}

Dari penelitian yang telah dilakukan di RSUP Prof. Dr. R. D. Kandou Manado pada periode 1 Januari sampai 31 Desember 2015 pada Tabel 1 didapatkan 31 persalinan prematur pada remaja dari 219 persalinan remaja.

Berdasarkan usia kehamilan persalinan remaja pada Tabel 2 didapatkan jumlah tertinggi yaitu aterm sebanyak 185 kasus $(84,47 \%)$. Kemudian pada usia persalinan prematur sebanyak 31 kasus $(14,15 \%)$, dan yang terendah yaitu postterm sebanyak 3 kasus $(1,36 \%)$. Jika dibandingkan dengan penelitian di RSUP Prof. Kandou Manado tahun 2013-2014, dimana distribusi kehamilan pada usia <20 tahun menurut usia kehamilan yang tertinggi yaitu aterm sebanyak 941 kasus $(88,28 \%)$. Berdasarkan hasil penelitian yang dilakukan di RS Margono Soekarjo Purwokerto sepanjang tahun 2009 disebutkan bahwa pada ibu hamil usia remaja sering mengalami komplikasi kehamilan yang buruk seperti persalinan prematur. Hal ini tidak sejalan dengan hasil yang didapatkan pada penelitian ini, pada tabel 2 dapat dilihat bahwa persalinan pada remaja paling banyak terjadi pada usia kehamilan aterm, yaitu sebanyak 185 kasus $(84,47 \%){ }^{25}$
Berdasarkan karakteristik menurut umur pada Tabel 3 didapatkan jumlah tertinggi pada umur 18-19 tahun yaitu sebanyak 22 kasus (70,96\%). Diikuti dengan kedua tertinggi pada umur 16-17 tahun sebanyak 6 kasus $(19,35 \%)$, yang terendah pada umur 14-15 tahun sebanyak 1 kasus $(3,22 \%)$ dan umur 12-13 tahun sebanyak 2 kasus (6,45\%). Jika dibandingkan dengan penelitian di RSUP Prof. Kandou Manado tahun 2013-2014 nilai tertinggi pada umur 18-19 tahun dengan jumlah 698 kasus $(65,48 \%)$. Pada teori menyebutkan bahwa usia $<20$ tahun merupakan faktor resiko, karena rahim dan panggul belum tumbuh mencapai ukuran dewasa. $^{25,26}$

Berdasarkan karakteristik menurut status pendidikan pada Tabel 4 didapatkan jumlah tertinggi pada SMA/SMK yaitu 20 kasus $(64,51 \%)$. Kemudian SMP sebanyak 8 kasus $(25,80 \%)$ dan SD sebanyak 3 kasus $(9,67 \%)$. Hasil penelitian ini sesuai dengan penelitian di RSUP Prof. Kandou Manado tahun 2015 dimana jumlah tertinggi didapatkan pada ibu yang mengalami persalinan prematur dengan tingkat pendidikan tertinggi SMA yaitu 86 kasus (56,95\%). Pada penelitian ini jumlah kasus tertinggi terjadi pada tingkat pendidikan SMA. Pendidikan biasanya dikaitkan dengan pengetahuan akan pentingnya pemeliharaan kandungan semasa kehamilan. Latar belakang pendidikan ibu yang rendah menyulitkan berlangsungnya suatu penyuluhan kesehatan terhadap ibu hamil, sehingga mereka tidak melakukan pemeliharaan kesehatan yang baik saat hamil. ${ }^{6}$

Berdasarkan karakteristik menurut pekerjaan ibu pada Tabel 5 didapatkan jumlah tertinggi pada IRT/Tidak bekerja sebanyak 29 kasus $(93,54 \%)$, dan yang terendah sebanyak 2 kasus $(6,45 \%)$ yaitu Mahasiswa. Hasil ini sesuai dengan penelitian di RSUP Dr. Soedarso Pontianak tahun 2008-2010 dimana jumlah tertinggi didapatkan pada IRT, yaitu sebanyak 227 kasus $(70,5 \%)$ dan hasil serupa didapatkan pada penelitian di RS. Santa Elisabeth Medan jumlah tertinggi adalah IRT 
sebanyak 106 kasus (50,2\%). Dari hasil yang didapatkan persalinan prematur tertinggi pada ibu rumah tangga. Pada teori disebutkan bahwa pekerjaan merupakan salah satu faktor pemicu terjadinya persalinan prematur. Persalinan prematur mungkin terjadi karena stress dengan banyaknya pekerjaan rumah tangga yang dilakukan pasien selama kehamilan. ${ }^{27}$

Berdasarkan status perkawinan pada Tabel 6 sebanyak 26 kasus $(83,87 \%)$ sudah menikah dan 5 kasus $(16,12 \%)$ belum menikah. Data UNICEF pada tahun 2001 Indonesia termasuk dalam lima besar negara-negara yang persentase pernikahan dini tertinggi di dunia. Berdasarkan SDKI tahun 2012 tercatat $4,8 \%$ menikah di usia 20-24 tahun dan 41,9\% menikah pada usia 15-19 tahun atau 41 per 1000 pernikahan. Dari data tersebut, dapat dilihat besarnya angka pernikahan dini di Indonesia. Berdasarkan data Depkes RI Di Indonesia kehamilan remaja tahun 2007 didapatkan data hamil diluar nikah karena diperkosa sebanyak 3,2\%, karena sama-sama mau sebanyak $12,9 \%$, tidak terduga sebanyak $45 \%$, dan seks bebas mencapai $22,6 \%$, hal ini terjadi karena minimnya pengetahuan remaja mengenai kesehatan reproduksi. ${ }^{28}$

Berdasarkan karakteristik menurut status paritas pada Tabel 7 didapatkan jumlah tertinggi pada primigravida sebanyak 25 kasus $(80,64 \%)$ dan terendah pada multigravida sebanyak 6 kasus $(19,35 \%)$. Saat ini cenderung terjadi pergeseran usia dimana seorang wanita melahirkan untuk pertama kali. Hal ini diperkirakan karena adanya perubahan lingkungan sosial yang mempengaruhi perilaku seksual yang berakibat pada kehamilan. $^{29}$

Berdasarkan karakteristik menurut penyulit dalam kehamilan pada Tabel 8 didapatkan jumlah tertinggi pada ketuban pecah dini (12,90\%), preeklampsi/ eklampsi (6,45\%), fluor albus $(3,22 \%)$, dan anemia $(3,22 \%)$. Hasil ini berbeda dengan hasil penelitian di RSUD Dr. Soedarso Pontianak tahun 2008-2010 yang menyatakan status obstetrik terbanyak adalah preeklampsi/eklampsi yaitu sebanyak 109 kasus (33,9\%). Pada teori disebutkan bahwa pasien dengan ketuban pecah dini, perdarahan antepartum, preeklampsi/ eklampsi merupakan faktor predisposisi terjadinya persalinan prematur. Dan pada penelitian ini didapatkan tertinggi pada pasien dengan ketuban pecah dini.

Presentasi janin pada persalinan remaja paling banyak yaitu, presentasi janin dengan letak kepala 28 kasus $(90,32 \%)$ sedangkan janin dengan presentasi letak sungsang sebanyak 3 kasus $(9,67 \%)$. Dalam penelitian ini tidak ditemukan janin dengan presentasi letak lintang. Hasil penelitian di Yordania dimana insiden tindakan bedah sesar lebih rendah pada kelompok usia muda dibandingkan dengan usia reproduksi. Begitu pula yang dilaporkan Ziadeh dimana tindakan bedah sesar dan persalinan pervaginam dengan instrumen lebih rendah pada kelompok usia muda. Hal ini diperkirakan akibat dari tingginya kejadian Berat Bayi Lahir Rendah (BBLR) pada kelompok usia muda yang berhubungan dengan lebih memungkinkan untuk melahirkan secara pervaginam. ${ }^{30}$

\section{SIMPULAN}

Berdasarkan hasil penelitian dan bahasan dapat disimpulkan bahwa insidensi remaja yang melahiran prematur di RSUP Prof. Dr. R. D. Kandou Manado periode 1 Januari-31 Desember 2015 sebesar 14,15\%, paling banyak pada kelompok usia 18-19 tahun dan sudah menikah. Persalinan pada remaja paling banyak terjadi pada usia kehamilan aterm dengan penyulit tertinggi yaitu ketuban pecah dini dan presentasi kepala tinggi.

\section{SARAN}

Perlu dilakukan penyuluhan tentang akibat perilaku seksual bebas dan pernikahan dini serta perwatan selama masa kehamilan.

Kepada orang tua, lebih memperhatikan pergaulan anak remaja saat masa pubertasnya. Untuk ibu hamil agar melakukan pemeriksaan rutin antenatal care di pusat kesehatan masyarakat setempat. 
DAFTAR PUSTAKA

1. Mochtar AB. Persalinan preterm. In: Prawirohardjo S, Saifuddin AB, editor. Ilmu kebidanan. Edisi ke-4. Jakarta: PT Bina Pustaka Sarwono Prawirohardjo; 2014. h. 667-676.

2. Sulistiarini D, Berliana SM. Faktor-faktor yang mempengaruhi kelahiran prematur di indonesia: analisis data riskesdas. E-journal widya kesehatan dan lingkungan. 2013;1:109-15.

3. Wijayanti MD. Hubungan usia dan paritas dengan kejadian partus prematurus di rumah sakit panti wilasa citarum semarang tahun 2010. Jurnal kebidanan panti wilasa. Vol. 2 No. 1, Oktober 2011.

4. Suspimantari C. Faktor risiko prematuritas yang berpengaruh terhadap luaran maternal dan perinatal berdasarkan usia kehamilan.[skripsi]. Semarang: Universitas Diponegoro; 2014.

5. Lessy S. Faktor risiko kejadian persalinan prematur di rskd ibu dan anak siti fatimah makassar tahun 2011. Makassar: Universitas Muslim Indonesia; 2011.

6. Oroh S. Karakteristik persalinan prematur di RSUP Prof. DR. R. D. Kandou Manado.[skripsi]. Manado: Universitas Sam Ratulangi; 2015.

7. Pratama ME. Pengaruh kehamilan usia remaja dengan kejadian persalinan prematur dan BBLR di RSUP Dr. H. Moch Anasari Saleh Banjarmasin tahun 2014. Dinamika kesehatan. 2015;6:87-97.

8. Manuaba IBG, Chandranita IA, Fajar IBG. Pengantar kuliah obstetri. Jakarta: EGC; 2007. h. 432-49.

9. Kosim MS. Gawat darurat neonatus pada persalinan preterm. Sari Pediatri. 2006; 7:225-31.

10. Indonesia di urutan kelima bayi prematur terbanyak. National geographic Indonesia. Diakses 05 September 2016. Diunduh dari http://national geographic.co.id/berita/2015/04/indo nesia-di-urutan-kelima-bayiprematur-terbanyak.

11. Constance S. Buku saku kebidanan. Jakarta: EGC; 2010. h. 195-200.

12. Chunningham FG, Leveno KJ, Bloom SL, et al. Obstetri williams. Edisi ke23. Jakarta: EGC; 2013. h. 846-70.

13. Manuaba IBG. Kapita selekta penatalaksanaan rutin obstetri ginekologi dan KB. Edisi pertama. Jakarta: EGC; 2001. h. 343-48.

14. Krisnadi SR, Pramatirta AY, Siddiq A, Sitanggang E. Panduan pengelolaan persalinan preterm nasional. POGI; 2011. h. 8 .

15. Destaria, Selvi. Perbandingan Luaran Maternal dan Perinatal Kehamilan Trimester Ketiga Antara Usia Muda dan Usia Reproduksi Sehat. Semarang: Universitas Diponegoro; 2011.

16. WHO. Adolescent health. Diakses pada 13 September 2016. Diunduh dari http://www.who.int/topics/adolescent health/en/.

17. BKKBN. Remaja dan Kesehatan Reproduksi. Jakarta: BKKBN; 2005.

18. Departemen Kesehatan RI. Profil Kesehatan Indonesia 2013. Jakarta: Pusat Data Kesehatan; 2014.

19. Niswah FI, Safitri H, Alqossam I, Rahayuningsih P. Hubungan kehamilan di usia remaja dengan kelahiran prematur di RSUD Tugurejo Semarang. Semarang: 2015.

20. Herawati, Susi. Kadar Progesteron estriol Saliva pada Ancaman Persalinan Prematur [disertasi]. Semarang: Universitas Diponegoro. 